American Journal of Applied Sciences 6 (1): 167-171, 2009

ISSN 1546-9239

(C) 2009 Science Publications

\title{
The Effects of Briquetting Pressure on Banana-Peel Briquette and the Banana Waste in Northern Thailand
}

\author{
Patomsok Wilaipon \\ Department of Mechanical Engineering, Faculty of Engineering, \\ Naresuan University, Phitsanulok, Thailand 65000
}

\begin{abstract}
Banana is considered as one of the most important agricultural products of Northern Thailand. A large amount of banana peel has been left as garbage after industrial processes. The raw material is plentiful and has low economic value. Therefore, the characteristics of banana-peel briquettes including banana peel properties were investigated. The briquettes were produced with pressures ranging from 3 to $11 \mathrm{MPa}$. Molasses was used as the binder. According to some standard tests, it was found that briquettes produced with compaction pressure over $7 \mathrm{MPa}$ passed both impact resistance and compressive strength tests. The density-pressure relationship and strength-pressure relationship over studied range were also developed and validated.
\end{abstract}

Key words: Banana peel, briquette, agricultural residue, biomass densification

\section{INTRODUCTION}

For most developing countries, it appears that biomass, particularly agricultural wastes, has become one of their most promising energy sources. The idea of utilizing the residues from agricultural sectors as primary or secondary energy sources is somewhat attractive sine they are available as free, indigenous and environmentally friendly ones. Furthermore, the decreasing availability of firewood has necessitated that efforts be made towards efficient utilization of agricultural wastes. They have acquired considerable importance as fuels for many purposes viz. domestic cooking, industrial process heating, power generation etc. Some of them, such as coconut shell, corn cob and wood waste, are ready to be directly used as fuel. The majority of them, however, are not appropriate to be used as fuel without a suitable process since they have low density, high moisture content, and low energy density. All of these issues may cause problems in transportation, handling, storage, entrained particulate emission control including direct combustion.

One of the optimistic technologies for alleviating these problems is briquetting, which has been studied by many researchers. The technology may be defined as a densification process for improving the handling characteristics of raw material and enhancing the volumetric calorific value of the biomass. Considerable amount of research on briquetting technology has been conducted. Examples of biomass studied are wheat straw $^{[1,2]}$ hazelnut shell ${ }^{[3]}$, $\operatorname{woods}^{[4,5]}$, grass ${ }^{[6,7]}$, $\operatorname{cotton}^{[8,9]}$, olive refuse ${ }^{[10]}$, rice straw and husk ${ }^{[11]}$ as well as maize $\operatorname{cob}^{[12]}$. Generally, it is agreed that conventional process for biomass briquetting may be divided into three main categories viz. extrusion, roll briquetting, as well as piston-and-die. For the case of the latter, the pressure is developed against the end of the die to form die-shape briquettes. During the processes, as the displacement of piston becomes less and less, the pressure inside the die is continuously increased. At the end of compaction process, the pressure is the highest and the briquette is formed.

Kingdom of Thailand, covering an area of $513,115 \mathrm{~km}^{2}$, is located in the center of mainland South East Asia. The total land boundary of Thailand is about $4,863 \mathrm{~km}$ in length. This country shares the borders with Myanmar to the west and northwest $(1,800 \mathrm{~km})$, Laos to the east and northeast $(1,754)$, Cambodia to the east $(803 \mathrm{~km})$, and Malaysia to the south $(506 \mathrm{~km})$. The south coast of Thailand faces the Gulf of Thailand. The Andaman Sea is on the west of the Isthmus of Kra while the Gulf of Thailand is on the east. Thailand is divided into four topographical regions viz. the mountains and forests of the north, the vast lowland of the central plains, the semi-arid farm lands of the northeast plateau, and the tropical islands and long coastline of the peninsula south. The country comprises 76 provinces that are further divided into districts, subdistricts and villages. The northern part of Thailand is a mountainous region comprising natural forests, ridges, lower foothill, and alluvial valleys. This region comprises 17 provinces namely, Chiang Mai, Chiang Rai, Tak, Kamphaeng Phet, Lampang, Mae Hong Son, Nakhon Sawan, Nan, Payao, Phetchabun, Phichit, Uthai 
Thani, Phitsanulok, Phare, Sukhothai and Uttaradit. With regard to the provinces, it can be divided into two distinct groups viz. the plain of the lower north from Nakhon Sawan to Sukhothai, and the mountainous upper north leading to borders of Myanmar and Laos.

One of the most important products of Northern Thailand is banana. This fruit is an important food crop cultivated for household consumption and market supply. The majority of bananas grown for commercial purposes are Pisang awak or Kluay Namwa, which is considered as an AAB (triploid) type. The production of this type of fruit does not pose any severe environmental risk. Therefore, the possibility of cultivating bananas in a sustainable way can be achieved. Generally, for banana industries in Thailand, bananas are harvested as a bunch. Then, they are delivered to a central point for inspection, cutting, curing, peeling, drying and/or other food processing prior to the packing processes at local small-factories or at village centers. After the peeling process, the banana peels are generally either uneconomically utilized or left to be disposed as they are.

The aim of the research was to investigate the properties of briquettes, produced from the blend of banana-peel and molasses. The piston-and-die technology was utilized for producing briquettes with moderate pressures ranging from 3-11 $\mathrm{MPa}$. Five parameters viz. compressive strength, impact resistance, heating value, burning profile and relaxed density were studied. Besides, the amount of potential energy from banana peel in Northern Thailand was also investigated.

\section{MATERIALS AND METHODS}

An ultimate analysis of the banana peel was conducted in accordance with ASTM D5373-02 $2^{[13]}$ and ASTM D5291-02 $2^{[14]}$, for getting the information about banana peel composition. With regard to ASTM E1131$03^{[15]}$, thermo gravimetric test of the banana peel was also carried out using a thermal gravity analyzer, Perkin Elmer. The condition used was under nitrogen atmosphere with a heating rate of $20^{\circ} \mathrm{C} \mathrm{min}{ }^{-1}$. The temperature studied was increased from room temperature to $850^{\circ} \mathrm{C}$ with an accuracy of $\pm 2{ }^{\circ} \mathrm{C}$. Furthermore, the heating value of the material was also examined according to ASTM E711-87 $7^{[16]}$ method. The calorimeter used was Parr isoperibol bomb calorimeter with an accuracy of $0.0001{ }^{\circ} \mathrm{C}$.

Size reduction of raw material, banana peel, is necessary before compaction. Thus, it was chopped into small pieces. Only the pieces that passed through a sieve with an opening of $2.8 \mathrm{~mm}$ were utilized in the experiments. Then banana peel was blended with molasses, which performs as the binder for briquetting process, with a ratio of 1:0.2. An electrical mixer was used at this stage. The mixture was blended until mould-condition was achieved.

Briquetting experiments were conducted by utilizing a semi-automatic laboratory hydraulic press. The machine was also fabricated with a pressure switch component to facilitate the pressure control. The accuracy of the pressure switch was $1 \%$ with a maximum pressure of $34 \mathrm{MPa}$. In order to form a briquette, a $38 \mathrm{~mm}$ ID $\times 100 \mathrm{~mm}$ height cylindrical die, made of hardened steel, was used. For each experiment, 100-gram of the blend, prepared by using an analytical balance with an accuracy of $\pm 0.001 \mathrm{~g}$, was filled into the die. The briquettes were produced under pressures ranging from 3-11 $\mathrm{MPa}$. The dwell time was set to $10 \mathrm{sec}$ for all experiments. All compaction experiments were conducted at laboratory conditions, 50-60\% humidity and $27^{\circ} \mathrm{C}$. Moreover, all samples were stored at this condition for one week before testing. Five briquettes were prepared for each set of the experimental conditions. Then, the arithmetic averages of the measurements were computed.

Some standards were adapted to determine the durability characteristics of the briquettes. According to the adapted version of drop shatter for coal, the investigation of impact resistance characteristic was conducted. In order to evaluate this characteristic, an Impact Resistance Index (IRI) was chosen as the criterion $^{[17]}$. Ten drops were set as a standard for all experiments. Only the number of pieces of $5 \%$ or more of the initial weight was recorded for the IRI calculation purpose.

The compressive strength of the briquettes was studied by using a universal testing machine. The accuracy of the machine was $\pm 0.5 \%$ with a maximum force of $50 \mathrm{kN}$. The flat surface of the sample was placed on the base-plate of the machine. With another plate parallel to the first one, the distance between two plates was slowly reduced by a motorized screw of the machine. The reduction of the distance was continued until the briquette cracking occurred. Then, the compressive strength was computed according to the briquette cross sectional area and the load at the fraction point. Furthermore, in order to understand the relaxation of the briquettes, the relaxed density of all samples was investigated. The volume of the briquettes was measured at 7 day after removal from the die. It was examined according to the ASAE S269.4 DEC96 ${ }^{[18]}$.

In order to validate the purpose equation, the coefficient of multiple determination for prediction $\left(\mathrm{R}^{2}\right.$ prediction $)$ was used for that purpose ${ }^{[19]}$. The value of 
$\mathrm{R}_{\text {prediction }}^{2}$ is between 0 and $100 \%$ which show the efficiency of the variability in predicting new observations.

$$
\mathrm{R}_{\text {prediction }}^{2}=1-\frac{\text { PRESS }}{\mathrm{SS}_{\mathrm{R}}+\mathrm{SS}_{\mathrm{E}}}
$$

where, PRESS is predict error sum of squares, $\mathrm{SS}_{\mathrm{E}}$ is the sum of squares due to residual and $\mathrm{SS}_{\mathrm{R}}$ is the sum of squares due to the regression.

\section{RESULTS AND DISCUSSION}

In order to estimate the amount of banana peel available in Northern Thailand, the residue-to-product ratio (RPR) of banana peel and the banana productivity of this area were utilized. According to the field measurement, it was found that the ratio was in the range of $0.16-0.39$. The value, 0.25 , was chosen for computing purpose. From data in 2003, it showed that the production of banana in this region was about $470.81 \mathrm{kt} \mathrm{year}^{-1}$. Therefore, the calculated amount of banana peel available in Northern Thailand was approximately $117.70 \mathrm{kt}$ year $^{-1}$. With regard to the heating value, the result showed that the higher heating value was $18.89 \mathrm{MJ} \mathrm{kg}^{-1}$. Hence, the estimated potential energy of banana peel in Northern Thailand was about 2,223 TJ year ${ }^{-1}$. Figure 1 shows the computed potential energy of banana peel available in each province of Northern Thailand. As can be seen from the figure, the area can be divided into five groups according to the values (A, B, C, D, and E). There are two provinces ( $\mathrm{A}$ and $\mathrm{B}$ ) with the energy content of banana peel over $400 \mathrm{TJ}_{\text {year }}{ }^{-1}$. Besides, the numbers of the provinces which possess the potential energy resource over $100 \mathrm{TJ}_{\text {year }^{-1}}$ are found to be four provinces (A, B, and $\mathrm{C}$ ). The energy of these four provinces together accounted for approximately $66 \%$ of the total energy content available in Northern Thailand.

In accordance with the test, it was found that the moisture content of the samples was approximately $15 \%$. Besides, the ultimate analyses results showed that the banana peel is comprised of $41.47 \%$ carbon, $5.68 \%$ hydrogen and $0.37 \%$ nitrogen. Furthermore, according to the burning profile investigation, it was found that the burning profile can be categorized into two main sections namely, rapid burning and slow burning. The first section of the burning, which starts from $175-400^{\circ} \mathrm{C}$, may be because of the release of some volatile matters including the ignition of the combustible part of the biomass. It was also found that

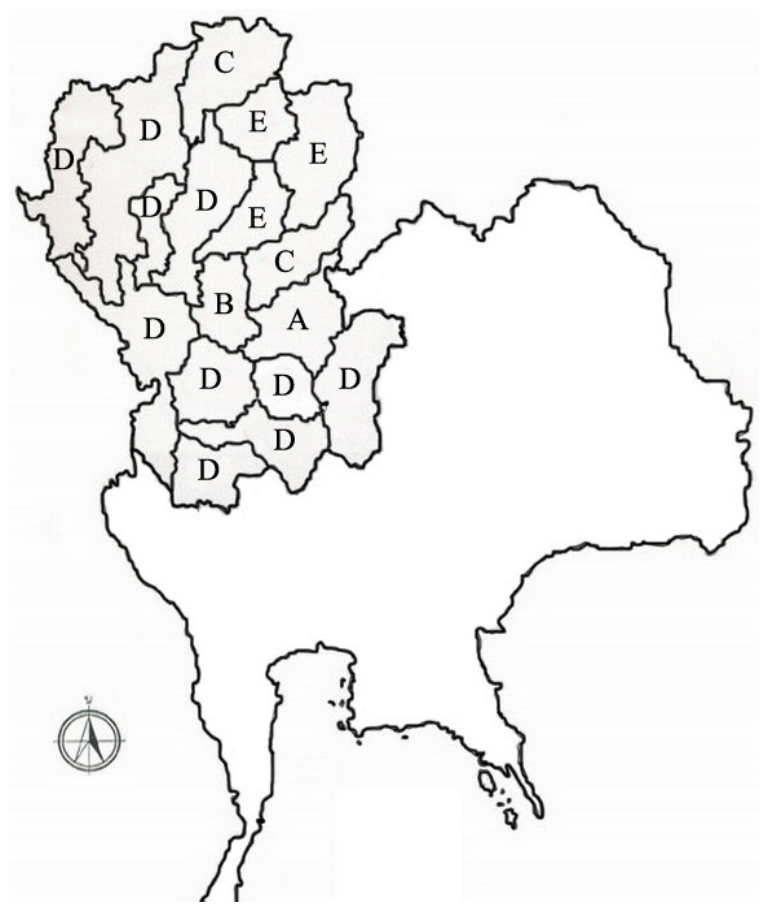

Fig. 1: Calculated energy of banana-peel in Northern Thailand (A500, 500B400, 400C100, 100D50, E50 TJ/year)

the maximum rate of mass loss was at $313^{\circ} \mathrm{C}$. More than a half of the combustible part of the material was burnt in this section. The latter section represents the slow burning region which the rates of these small mass losses were less than $2.5 \mathrm{mg} \mathrm{min}^{-1}$. These small losses of mass continued until the temperature was increased to $850^{\circ} \mathrm{C}$.

One of the most important parameter in briquetting is relaxed density. Several factors such as the bulk density of biomass and briquetting pressure affect the density of biomass briquettes. From the experiment, it was found that the maximum relaxation took place within the first period after removing from the die. Then it was followed by a gradually decrease in the rate of relaxation until almost stable at one week. The relaxed density of the briquettes was measured at 7 days after the briquetting process. The exponential relationship between die pressure and relaxed density over the studied range is as the following:

$$
\mathrm{D}=-1.15385 \mathrm{P}^{2}+30.15071 \mathrm{P}+839.65602
$$

where, $\mathrm{P}$ is pressure in $\mathrm{MPa}, \mathrm{D}$ is the density in $\mathrm{kg} \mathrm{m}^{-3}$. The calculation result shows that coefficient of multiple determination for prediction is $94 \%$. 
Some experiments were conducted to determine the effects of briquetting pressure on the durability of the briquettes. Two parameters, Impact Resistance Index (IRI) and Compressive Strength (CS), were studied. The IRI values were calculated from the following equation: IRI $=$ (number of drops $\times 100$ )/number of pieces that the briquette broke into. As the target value of IRI was 100, it was found that all briquettes produced with briquetting pressures ranging from 5-11 MPa passed the tests. Moreover, it may be noted that the briquettes with compaction pressure over $5 \mathrm{MPa}$ d id not shattered into pieces, in other words, the IRI values for these cases were 1000 .

The latter parameter, compressive strength, was calculated from the following equation: $\mathrm{CS}=$ the load at the fracture point/the cross-sectional area of the briquette. It was found that the $11 \mathrm{MPa}$ briquette accounted for the highest strength-values, approximately $830 \mathrm{kPa}$. Nevertheless, the strength values of 7 and $9 \mathrm{MPa}$ briquettes are close to the highest value. The relationship between the compressive strength and die pressure over the studied range is as the following:

$$
\mathrm{S}=0.002556 \mathrm{P}^{3}-0.065260 \mathrm{P}^{2}+0.549294 \mathrm{P}-0.714450
$$

where $\mathrm{S}$ and $\mathrm{P}$ are compressive strength and pressure in $\mathrm{MPa}$, respectively. The calculation result shows that coefficient of multiple determination for prediction is $90 \%$.

\section{CONCLUSION}

Banana-peel briquettes produced with pressures ranging from 7-11 MPa passed both impact resistance and compressive strength tests. Moreover, the briquette density was found to increase with an increase in briquette pressure. Finally, density-pressure relationship and strength-pressure relationship, which shows good agreement with the experimental results, were also developed with the coefficient of multiple determination for prediction of 94 and $90 \%$, respectively.

\section{REFERENCES}

1. Demirbas, A., 1999. Physical properties of briquettes from waste paper and wheat straw mixtures. Energy Convers. Manage., 40: 437-445, doi: 10.1016/S0140-6701(99)97867-0.

2. Demirbas, A. and A. Sahin, 1998. Evaluation of biomass residue 1: Briquetting waste paper and wheat straw mixtures. Fuel Process. Technol., 55: $\quad 175-183, \quad$ doi: $10.1016 /$ S03783820(98)00041-1.
3. Demirbas, A., 1999. Properties of charcoal derived from hazelnut shell and production of briquettes using pyrolytic oil. Energy, 24: 141-150, doi: 10.1016/S0360-5442(98)00077-2.

4. Granada, E., L.M.L. Gonzalez, J.L. Miguez and J. Moran, 2002. Fuel lignocellulosic briquettes, die design and products study. Renewable Energy, 27: $561-573, \quad$ doi: $10.1016 /$ S09601481(02)00005-8.

5. Li, Y. and H. Liu, 2000. High-pressure densification of wood residues to form an upgraded fuel. Biomass Bioenergy, 19: 177-186, doi: 10.1016/S0961-9534(00)00026-X.

6. Finell, M., C. Nilsson, R. Olsson, R. Agnemo and S. Svensson, 2002. Briquetting of fractioned reed canary-grass for pulp production. Ind. Crops Prod., 16: $\quad 185-192, \quad$ doi: $10.1016 /$ S09266690(02)00036-5.

7. Paulrud, S. and C. Nilsson, 2001. Briquetting and combustion of spring-harvested reed canary-grass: Effect of fuel composition. Biomass Bioenergy, 20: 25-35, doi: 10.1016/S0140-6701(02)85242-0.

8. Singh, R.N., 2004. Equilibrium moisture content of biomass briquettes. Biomass Bioenergy, 26: $\quad 251-253, \quad$ doi: $10.1016 / \mathrm{S} 0140-$ 6701(04)80027-4.

9. Coates, W., 2000. Using cotton plant residue to produce briquettes. Biomass Bioenergy, 18: $\quad 201-208, \quad$ doi: $10.1016 /$ S09619534(99)00087-2.

10. Yaman, S., M. Sahan, H. Haykiri-acma, K. Sesen and S. Kucukbayrak, 2000. Production of fuel briquettes from olive refuse and paper mill waste. Fuel Process. Technol., 68: 23-31, doi: 10.1016/S0378-3820(00)00111-9.

11. Ndiema, C.K.W., P.N. Manga and C.R. Ruttoh, 2002. Influence of die pressure on relaxation characteristics of briquetted biomass. Energy Convers. Manage., 43: 2157-2161, doi: 10.1016/S0196-8904(01)00165-0.

12. Wilaipon, P., 2007. Physical characteristics of maize cob briquette under moderate die pressure. Am. J. Applied Sci., 4: 995-998, http://www. scipub.org/fulltext/ajas/ajas412995-998.pdf.

13. ASTM Standard D5373-02, 2003. Standard Test Methods for Instrumental Determination of Carbon, Hydrogen and Nitrogen in Laboratory Samples of Coal and Coke, ASTM International, West Conshohocken, PA, www.astm.org.

14. ASTM Standard D5291-02, 2003. Standard Test Methods for Instrumental Determination of Carbon, Hydrogen and Nitrogen in Petroleum Products and Lubricants: Test Method B, ASTM International, West Conshohocken, PA, www.astm.org. 
15. ASTM Standard E1131-03, 2004. Standard Test Method for Compositional Analysis by Thermogravimetry, ASTM International, West Conshohocken, PA, www.astm.org.

16. ASTM Standard E711-87, 2004. Standard Test Method for Gross Calorific Value of RefuseDerived Fuel by the Bomb Calorimeter, ASTM International, West Conshohocken, PA, www.astm.org.

17. Chin, O.C. and K.M. Siddiqui, 2000. Characteristics of some biomass briquettes prepared under modest die pressure. Biomass Bioenergy, 18: 223-228, doi: 10.1016/S09619534(99)00084-7.
18. ASAE Standard S269.4, 1991. Cubes, pellets and crumbles-definitions and methods for determining density, durability and moisture content, ASABE, St. Joseph, MI, www.asabe.org.

19. Myers, R.H. and D.C. Montgomery, 2002. Response Surface Methodology. John Wiley \& Sons, USA, www.wiley.com. 